\title{
Om Grundtvigs sanges liv i Nordamerika
}

\section{Af Marianne Stølen}

I artiklen diskuteres tre væsentlige betingelser for det rige liv, Grundtvigs sange har fået hos dansk-amerikanerne i Nordamerika. Først behandles Frederik Lange Grundtvigs sangværk, Sangbog for det danske Folk i Amerika (1888), almindelig kendt som "den røde", med fokus på F. L. Grundtvigs udvalg af kendte og ukendte sange og salmer hentet fra faderens sangskat og hans bearbejdelser af nogle af disse med henblik på brugerrelevans hos de danske emigranter. Dernæst beskrives sangproduktionen hos udvandrerne, specielt de danske præster, med eksempler på ordvalg, der viser afsmitning af nøglefod fra Grundtvigs forfatterskab samt let genkendelige ekkolinjer fra Grundtvig-klassikerne. Opfølgende beskrives salmebogen Hymnal for Church and Home (1927) og den dansk-amerikanske sangbog A World of Song (1941), der hver på sin måde medvirkede til at bygge bro mellem generationer af brugere. Den dansk-amerikanske oversætter og præst S. D. Rodholms oversættelsesbidrag til sangbogen fremhæves med brug af eksempler fra Grundtvigs forfatterskab. Endelig gives der indblik i den rolle, Grundtvigs sange spiller i sangrepertoiret i dag på dansk-amerikanske konferencer og hos nuværende medlemmer af to sanggrupper i The Pacific Northwest.

\section{Sangbog for det danske Folk i Amerika (1888)}

I diskussionen herunder trækkes på Henning Høirups bidrag om F. L. Grundtvigs liv og litterære indsats i mindeskriftet, Frederik Lange Grundtvig (Høirup 1955), i særdeleshed afsnittet "Sangbog for det danske Folk i Amerika". Endvidere inddrages nærværende forfatters forskning inden for området dansk sang i Amerika og langvarige feltarbejde blandt dansk-amerikanere i staten Washington (fra midten af 1980'erne til dags dato).

Sangbogen (1888) - den sidste (7.) udgave fra 1949 - udgør F. L. Grundtvigs primære bidrag til sine landsmænds åndsliv i løbet af hans næsten tyve år lange virke som præst og igangsætter af danske kolonier i det nye hjemland (1881-1901) - "den ubetinget ejendommeligste Frugt af vort danske Aandsliv paa amerikansk Grund", som hans ven, præsten Th. Helweg, ${ }^{1}$ betegnede sangværket. Sangbogens brogede indhold, især i den udvidede anden udgave (1891), inkluderede adskillige eksempler fra faderens sangskat, som aldrig før eller sjældent havde været $\mathrm{i}$ brug. Som et slående eksempel henviser Høirup til to strofer af "Menneske først og Christen saa", et digt, der først blev fundet frem efter Grundtvigs død (Høirup 1955, 153-154). ${ }^{2}$ F. L. Grundtvigs musikalske evner fik rige udfoldelsesmuligheder i melodier til sangbogens tekster, heriblandt ovenstående indled- 
ningsdigt af faderen (sangbogens nr. 2). De øvrige Grundtvig-sange og -salmer, specielt sangbogens første numre, er ligeledes værd at se nærmere på. Med Høirups ord: "Grundtvigs særlige syn paa folk og menneske kommer i sønnens sangbog langt klarere til orde end i de første udgaver af vor hjemlige højskolesangbog" (Høirup 1955, 154). Gennem sangværket kunne F. L. Grundtvig yde sit til, at faderens tanker om det folkelige og kristelige kunne leve videre blandt danske udvandrere og deres efterkommere.

Et godt eksempel på levedygtigheden af Grundtvigs programmatiske sange og salmer er en engelsksproget salme om Ordet forfattet af den dansk-amerikanske præst og oversætter S. D. Rodholm. I den tosprogede dansk-amerikanske sangbog, Sange for Danskere: Songs of Denmark. Songs to Live By (Ibsen, 2005), findes Rodholms bidrag fra 1940, 'The Word". Som bogens udgiver Joy Ibsen forklarer i bogens post scriptum, er digtet en tilpasning af Grundtvigs ideer. ${ }^{3}$ Rodholms digt på fire strofer har melodi af dansk-amerikaneren Aage Sorensen. Det blev trykt første gang i AWOS (1940 og 1956). Første strofe lyder: "With the Word all things began, / Life in the ocean, life on land; / With the Word were man and woman / Raised from dust, created human, / Prince of earth and child of God, / Prince of earth and child of God."

\section{F. L. Grundtvig - tilskæreren}

I en fodnote til afsnittet om sangbogen opfordrer Høirup til en undersøgelse af "F. L. Grundtvigs sangbearbejdelser af faderens forfatterskab" (Høirup 1955, 154), en opfordring hermed taget til følge, om end som et pilotprojekt. F. L. Grundtvig foretog betydelige ændringer og gendigtninger af såvel sangbogens Grundtvig-sange og -salmer som tekster generelt fra den danske folkelige sangarv. Høirup henviser i den forbindelse til F. L. Grundtvigs indlæg i Dannevirke (1887 og 1888), tidens danske immigrant-ugeavis (Høirup 1955, 149-151) ${ }^{4}$. Her redegør F. L. Grundtvig for sine bevæggrunde for tekstændringerne undskylder endog herfor, eftersom han ikke har underrettet forfatterne i Danmark herom. Han var "bange for at faa et Afslag". I samme åndedræt beder han om forståelse for, "at vi ikke her i Amerika kan synge Sangene uden Forandringer, og der er endnu ingen iblandt os, som har Evne til at skabe en ny Sang for vort Folk herovre".

Med afsæt i typiske eksempler på F. L. Grundtvigs tekstændringer af kendte sange (for eksempel Hostrups "Vi fik ej under Tidernes Tryk" ) pointerer Høirup endvidere, at F. L. Grundtvig ikke forestillede sig, at hans tekstændringer ville forbedre sangene, derimod at deres brugsværdi i Amerika ville højnes: "I mangfoldige af de medtag- 
ne sange ændres blot udtryk, som af geografiske eller historiske grunde ikke passer i Amerika" (Høirup 1955, 151).

I nedenstående fokuseres på tekster fra Grundtvigs forfatterskab. Teksterne indgår ikke i det materiale fra den danske sangskat, hvorfra Høirup hentede sine eksempler til belysning af tendenser i F. L. Grundtvigs tekstændringer. Mig bekendt har de heller ikke været genstand for andre forskeres (publicerede) analyser. Først en anekdote fra mit feltarbejde blandt dansk-amerikanerne i The Northwest. Den repræsenterer et aspekt af samtidens perspektiv på F. L. Grundtvigs ændringer - ja, til hele ideen om at forandre noget velkendt og elsket og er i tråd med digteren Adam Dans øgenavn til F. L. Grundtvig: "Tilskæreren". Anekdoten stammer fra midten af 1980'erne, det vil sige ca. hundrede år efter, at F. L. Grundtvig foretog sine ændringer og omdigtninger.

Efter deltagelse $i$ et sangfællesskab med en gruppe dansk-amerikanere kom jeg under kaffebordet i samtale med en tidligere dansk præst, en andengenerations dansk-amerikaner. Talen faldt på F. L. Grundtvig og hans liv og virke i Amerika. Navnet F. L. Grundtvig affødte følgende vrede udbrud: "He butchered his father's songs!" Det hører med til anekdoten, at ytringen er et ekstremt eksempel på en negativ holdning til F. L. Grundtvigs omformuleringer af Grundtvigs sange og salmer. Vurderingen af F. L. Grundtvigs arbejde fra en af hans samtidige, den dansk-amerikanske præst A. Bobjerg, repræsenterer den diametralt modsatte holdning til tekstændringerne, for det meste gjort "med virkeligt Digtersnille (...) Alene ved dette Arbejde har Grundtvig indskrevet sit Navn i det dansk-amerikanske Folks Historie" (Høirup 1955, 152).

Helt så stærkt som slagtning var Adam Dans opfattelse af vennen pastor Grundtvigs bebudede ændringer af udvalgte tekster i sangbogen ikke. Anden strofe af Dans lille digt i Dannevirke (9. 2, 1887), citeret af Høirup, lyder: "De store Sangeres Poesi / man kan jo saa næmt tilskære! / Det er et 'frit Country', vi lever i, / og Tilskærerkunsten i Ære!” (Høirup 1955 150). Som Høirup bemærker, blev "den lille Skærmydsel" mellem de to digterpræster hurtigt udvisket. Vidnesbyrd herom er bl.a. F. L. Grundtvigs melodi til Dans "Jeg tror paa en Folkefornyelsens Dag" og det smukke mindedigt, som Dan skrev ved sin vens død. Endnu et bevis er en udgave af Adam Dans digtsamling Kilder i Dalen (1889), tilegnet F. L. Grundtvig: "Digteren og Vennen Præsten F. L. Grundtvig, fra Adam Dan" står der under bogtitlen. Udgaven, lokaliseret af nærværende forfatter, befinder sig i Det Kongelige Biblioteks arkivsamling (Magasin, Danske Afdeling, KBS $\left.4,-2258^{\circ}\right)$. 
Såvel ændringer af verslinjer indlært i barndommen - hvad Haack (1980) benævner 'huskevers', herunder Grundtvig-klassikere - som udskiftning af melodier kunne, og kan, afstedkomme negative reaktioner. Tekst og melodi udgør en tandem-enhed. I en danskamerikansk sangkontekst var der ydermere det problem, at der til fællessang ved mange sammenkomster fandtes et stort udvalg af sangmateriale - fra yndlingssanghæfter medbragt fra Danmark, til Højskolesangbogen - alle med de oprindelige velkendte tekster og melodier. Dette materiale ville blive benyttet side om side med F. L. Grundtvigs sangbog samt sangbøger og hæfter udgivet i Amerika, hvor F. L. Grundtvigs tekstændringer sandsynligvis indgik. Fællessangens grundlæggende samstemning var $\mathrm{i}$ fare for at blive erstattet af disharmoni, hvis der $\mathrm{i}$ en given valgt sang forekom strofer med forskellig ordlyd.

\section{Eksempler på F. L. Grundtvigs tilskæring af faderens sangskat}

Der gives i sangbogens indledning en kort indføring i F. L. Grundtvigs tekstændringssystem. Én asterisk betyder, at "Sangen er ændret af Udgiveren". To viser, at "Sangen i høj Grad er ændret". Ikke alle ændrede tekster overlevede til sidste udgave af sangbogen (1949), men for dem, som gjorde, forblev teksten uændret. Fra og med femte udgave er der ingen markering af de sange, der var blevet ændret af F. L. Grundtvig. Det formodes, at den manglende markering var en bevidst udeladelse fra udgivernes side. Fra femte udgave blev det skønnet, at sangene i deres ændrede version udgjorde en del af de danske immigranters sanghukommelse - med andre ord, en del af den dansk-amerikanske kanon.

Gradueringssystemet er til tider inkonsekvent. En sang med samme tekstændringer kan således i første udgave have én asterisk, i den følgende være udstyret med to. Nærværende forfatter betragter dette som en afspejling af F. L. Grundtvigs arbejdsbetingelser. I ovenstående Dannevirke-citat, hvori F. L. Grundtvig omtaler ændringer af sange foretaget uden forfattertilladelse, giver han som delvis undskyldning "vor Nødstand". Der var et udtalt behov for en gedigen sangbog med relevans for tidens brugere. F. L. Grundtvigs arbejde med sangværket fandt sted samtidig med hans dybe engagement i præstegerningen i Clinton, Iowa, og i arbejdet med at etablere danske kolonier. Med andre ord arbejdede han under et enormt tidspres. Mindre unøjagtigheder kunne næppe undgås, hvis værket skulle i trykken i årtiet inden århundredskiftet. 
Hvad F. L. Grundtvig giver betegnelsen "læmpelige" forandringer, er som regel mindre indgreb i teksten - udskiftning af enkelte ord, ændringer af dele af enkeltlinjer. Hans musikalitet - her i form af overvejelser omkring prosodi og rim - spillede helt klart en rolle $\mathrm{i}$ vurderingen af nye ord, der i såvel indhold som form kunne erstatte den oprindelige tekst. De mere drastiske ændringer, hvoraf der var langt færre, bestod af udskiftning af store dele af et digt, tilføjelser af linjer eller strofer eller beskæringer af samme.

\section{Tekster med "læmpelige" tekstændringer}

Som et eksempel på en skånsom ændring af en velkendt sang fra faderens hånd er valgt "Vi har en gammel Kjærlighed" (1846). F. L. Grundtvig gav digtet titlen "Vor gamle Arv". Hans omdigtede tekst har făet tildelt én asterisk. Nedenfor præsenteres digtets sjette og sidste strofe først i den originale version, dernæst i omdigtet form. De ændrede linjer er fremhævet.

\section{N. F. S. Grundtvigs digt:}

Vi har en gammel Kjærlighed som ruster ingenlunde,

til Fædres Land, til Lys og Fred, til Bælter og til Sunde; den blusse op, den bryde ud i Daad, i Sang og Tale! da, som en Bejler til sin Brud, til os skal Lykken dale!

\section{F. L. Grundtvigs version:}

Vi har en gammel Kjærlighed som ruster ingenlunde, til Kæmpeliv for Lys og Fred, selv fjærnt fra Danmarks Sunde! den blusse op, den bryde ud i Daad, i Sang og Tale! Da som en Bejler til sin Brud til os skal Lykken dale!

Med elegant håndelag - udskiftning af blot få elementer - blev Grundtvigs digt gjort relevant og sangbart for brugere "fjærnt fra Danmarks Sunde". Som et kuriosum kan nævnes endnu en mindre ændring: udskiftning af fjerde linjes semikolon med et udråbstegn. Hermed blev der lagt ekstra vægt på dansk-amerikanernes nye kontekst. I det totale korpus af ændrede sange er der talrige eksempler på udskiftning af et tegn i originalteksten med et udråbstegn. Som sin far var F. L. Grundtvig en flittig bruger af udråbstegnet.

Yderligere tre eksempler er hentet fra kategorien "læmpelige" tekst-ændringer (begge udstyret med én asterisk). Det første digt, "Dig rummer ei Himle" (1830), fik titlen "Kirker paa Jord". En ven af F. L. Grundtvig, F. P. J. Lund, bidragyder med adskillige melodier til sangbogens indhold af sange og salmer, skrev en melodi dertil. De nænsomme ændringer berørte såvel stavning som vokabularium. Digtet blev reduceret til syv strofer fra de oprindelige fjorten. 
Stroferne 2 og 3, svarende til originalens str. 6 og 7, følger nedenfor. En udskiftning af adverbiet 'Thi' med 'Dog' i str. 2 afstedkom betydningsændring, og forandringerne $\mathrm{i}$ str. 3 gjorde digtet mindre abstrakt og mere mundret.

\section{N. F. S. Grundtvigs digt:}

Thi bygge vi Kirker, hvor Guds-Ordet virker, i Lys og i Løn, hvor Hjertet sig fryder, naar Hallen gjenlyder af Tak for Guds Søn!

Ja, lægges de øde, det volder de Døde, som spøge i dem, thi alle medgivet er Lysten til Livet i Glædernes Hjem!

\section{F. L. Grundtvigs version:}

Dog bygge vi Kirker, hvor Guds-ordet virker, i Lys og i Løn, hvor Hjertet sig fryder, naar Hallen gjenlyder af Tak for Guds Søn.

Og lægges de øde, det volder de Døde, som spøger i dem; thi alle Du givet har Lysten til Livet i Glædernes Hjem.

I Grundtvigs digt "Ingen har Guldtaarer fældet" (1855), som fik titlen "Guds Ord og Guds Billed", praktiseres nogle af de samme principper som i ovenstående eksempel. Det oprindelige digt blev forkortet (fra tretten strofer til ti). Ved at foretage nogle få, om end væsentlige ændringer i den omdigtede versions strofe 5 og strofe 9 (hvad der i Højskolesangbogens attende udgave (2006) svarer til stroferne 4 og 8) opnår F. L. Grundtvig en væsentlig ændring i fokus ("Fædres Land" udskiftet med "eget Land") af betydning for sangbogens brugere. I strofe 9 afstedkommer en udskiftning af det demonstrative pronomen "det" med det forstærkende adverbium "dog" en yderligere betoning af udråbet. Endelig anvender F. L. Grundtvig kursiv i sin fremhævelse af "Guds Ord".

\section{N. F. S. Grundtvigs digt:}

Er os tomme Ord og Lyde eget Folk og Fædres Land, ved vi ej, hvad de betyde mer end Mængde, Muld og Sand, Tant er og hvert Ord, vi tale Om Guds Riges Bjærg og Dale, Om Guds Folk og Menighed.

Mærker det, I Børn og Kvinder! mærke det hvert Hjærte varmt! magtesløst Guds Ord I finder, koldt og dødt og mørkt og armt,

\section{F. L. Grundtvigs version:}

Er os tomme Ord og Lyde eget Folk og eget Land, ved vi ej, hvad de betyde mer end Mængde, Muld og Sand, Tant er og hvert Ord, vi tale Om Guds Riges Bjærg og Dale, Om Guds Folk og Menighed.

Mærker dog, I Børn og Kvinder, mærker dog, hvert Hjærte varmt! magtesløst Guds Ord I finder, koldt og dødt og mørkt og armt, 
når ej med den Røst det klinger, som fik Liv og Kraft og Vinger hos os ved Guds Aandepust. naar ej med den Røst det klinger, som fik Liv og Kraft og og Vinger hos os ved Guds Aandepust.

Kategoriens sidste eksempel er Grundtvigs fem-strofers digt "Er Lyset for de Lærde blot" (1839). F. L. Grundtvig valgte som passende titel hertil "Oplysning". Hans ændringer bestod af omdigtning af enkelte linjer og en enkelt ændring i tegnsætningen. I anden strofe stiller N. F. S. Grundtvig to centrale (retoriske) spørgsmål til sin målgruppe, begge afsluttet med et spørgsmålstegn. I F. L. Grundtvigs version bliver spørgsmål nummer to afsluttet med et udråbstegn og får dermed karakter af emfatisk erklæring. Endvidere ændrede han i fjerde strofe to linjer, så målgruppen blev udvidet - fra dem, der boede ved "Nordens Pol", til "her [det nye hjemland], som hist ved Nordens Pol" (linje 5). Forandringen medførte en yderligere ordudskiftning i den følgende linje, hvorved linjens centrale betydning blev bevaret og ligeså dens rytme. I første linje af samme strofe giver en ændring af et enkelt ord - præpositionen "fra" ændret til "til" - betydningsforskydning i tråd med ændringen i linje 5.

\section{N. F. S. Grundtvigs digt:}

Er Lyset i Planeten kun, som ej kan se og mæle? Er ikke Ordet i vor Mund et Lys for alle Sjæle?

Det giver os for Aander Syn som Solens Skin for Kroppe, det slaar i Sjælen ned som Lyn fra Skyerne hist oppe.

Nej, aldrig spørges det fra Nord, vi Lyset vil fordunkle!

Som Nordlys i fribaarne Ord det saas paa Himlen funkle, og ses det skal ved Nordens Pol, ej blot i Kroppens Rige; Midsommerens den bolde Sol vil ej for Midnat vige!

\section{F. L. Grundtvigs version:}

Er Lyset i Planeten kun, som ej kan se og mæle? Er ikke Ordet i vor Mund et Lys for alle Sjæle!

Det giver os for Aander Syn, som Solens Skin for Kroppe, det slaar i Sjælen ned som Lyn fra Skyerne hist oppe.

Nej, aldrig spørges det til Nord, vi Lyset vil fordunkle!

Som Nordlys i fribaarne Ord det saas paa Himlen funkle, og her, som hist ved Nordens Pol, skal ses i Aandens Rige; Midsommerens den bolde Sol vil ej for Midnat vige.

\section{Eksempler fra kategorien de “i høj Grad” ændrede tekster}

"Der blinker en Stjærne / I Solebjærgslag", Grundtvigs lejlighedsdigt fra 1819, repræsenterer en unik blomst i F. L. Grundtvigs farvestrålende blomsterkrans af almindelige og mere sjældne blomster. Den konkrete lejlighed for digtets tilblivelse var Grundtvigs ven, professor 
Carl Ottos "Tiltrædelse til en Udenlandsrejse". Der skulle gå mange år, før digtet kom på tryk - først i 1883. Svend Grundtvig, ${ }^{6}$ som redigerede faderens poetiske skrifter, fandt $\mathrm{i}$ bind $\mathrm{V}$ plads til digtet. Som Grundtvigs digt "Først Menneske ret, og Kristen saa", havde lejlighedsdigtet behov for en melodi. F. L. Grundtvig valgte en populær melodi af H. O. C. Zinck, digtets form blev tilpasset melodien, og nogle indholdsmæssige ændringer fandt ligeledes sted. Det blev udstyret med to asterisker, hvilket kan undre, hvis man sammenligner med det noget mere ændrede digt "Dagen med sit lyse Øje", som diskuteres nedenfor. Dette digt har samme gradering. Som ovenfor nævnt var gruppeplaceringerne til tider noget vilkårlige. "Der blinker en Stjærne" blev ikke en varig blomst i sangbuketten. Sangen er kun at finde i de to første udgaver af sangbogen, det vil netop sige de to, som F. L. Grundtvig var hovedredaktør for.

Grundtvigs bekendtskab med Oehlenschläger, Goethe og Shakespeare, såvel som hans interesse for Nordens myter, folkesagn og folkemål, går helt tilbage til de unge år. Et godt eksempel på hans brug af folkemål er "Solebjærgslag", af Grundtvig defineret som " i FolkeMund Solens Nedgangs-Tid" (Skautrup 1953, 334). I Grundtvigs symbolverden diskuterer Helge Toldberg (Toldberg 1950, 72) Grundtvigs forståelse og anvendelse af myter. Han fremhæver her Grundtvigs definition af en myte som "et Gaade-ord". Søren Holm (Holm 1955, 11) påpeger endvidere, hvorledes vi overalt i Grundtvigs digteriske produktion møder myten, "snart som Billeder og snart som den rene Virkelighed, og det er ikke altid lige let at se, hvad der er Virkelighed, og hvad der blot er Symbol." I ovennævnte digt anvender Grundtvig eksempelvis Signelil - ifølge et sagn hos Saxo en kongedatter i Ringsted - som symbol på trofasthed. Med F. L. Grundtvigs behændige tilskæring blev digtet til en sang om pionerernes urokkelige trofasthed og stærke bånd til hjemlandet. Det ændrede digt bibeholdt i øvrigt Grundtvigs centrale ide om Aftenstjernen, der med sit "Kjærlighedsblink" skaber forbindelse til "Dannemænd i det Fjærne". Digtet fik titlen, "Danmarks Stjærne". Dets nye iklædning som immigrantsang afspejler en typisk genre-tilpasningsproces for meget af det materiale F. L. Grundtvig ændrede, før det fik plads i sangbogen. Et digt skrevet til en bestemt person eller lejlighed kunne med få ændringer og sat til melodi fungere som samlingssang for et bredt immigrantpublikum. Et tidligere "usynligt" digt af Grundtvig blev mere synligt og medvirkede dermed til at formidle faderens ideer om det kristelige og folkelige. Nedenfor følger anden og tredje strofe af forlægget og den ændrede version af digtet på i alt tre strofer. 
N. F. S. Grundtvigs digt:

Ja, Danemarks Stjærne

Med Kjærligheds Blink

Af Dagmar et Vink

Til Danemænd er i det fjærne:

Om Troskabens Dyd,

Om Vemodens Fryd,

Om Hjærtet, som ganger for Hjærne.

Til Signelils Stjærne

Som blinker saa blidt,

Se mildt og se tit!

I Øjet sig spejler den gjærne;

Da farer du vel

I Dagning og Kvæld

Er Danemark nær i det fjærne
F. L. Grundtvigs version:

Ja, Danemarks Stjærne med

Kjærligheds Blink

Om Minder fra Hjemmet vil værne, Ja, Danemarks Stjærne af Dagmar et Vink

til Danemænd er i det fjærne:

om Troskabens Dyd, om Vemodens Fryd,

om Hjærte, som ganger for Hjærne.

Til Signelils Stjærne, der blinker saa blidt,

Som Solkongens lysende Terne

Til Signelils Stjærne se mildt og se tit!

i Øjet den spejler sig gjærne;

da farer du vel

i Dagning og Kvæld,

er Danemark nær i det fjærne.

"Dagen med sit lyse Øje" er det sidste eksempel på F. L. Grundtvigs tilpasning af et digt af faderen, før dette blev optaget i sangbogen. Digtet på seks strofer stammer fra det historiske år 1849, hvor Danmark fik sit første demokratiske parlament, Rigsdagen, og markerer denne for landets indbyggere positive begivenhed. Grundtvig var året før blevet medlem af den Grundlovgivende Rigsforsamling. I digtet lægges der op til to forskellige udlægninger af ordet 'Dagen' tidsafsnittet og '(rigs)dagen.' Grundtvig gav sit digt titlen "Rigsdagen". I F. L. Grundtvigs titel "Dagens Pris" spilles der ligeledes på en dobbelthed - 'Pris' tolket som omkostninger og 'Pris' beslægtet med verbet, 'at (lov)prise.' Både Grundtvigs og F. L. Grundtvigs fine sans for sprogets nuancer er her eksemplificeret.

I de første strofer følger F. L. Grundtvig stort set forlæggets ordvalg og form. Undtagelsen er en forudsigelig udskiftning af ordet "Danevang" med "Folkevang" (str. 3) og efter samme mønster en elegant ændring af femte strofes første linje, "Dag for hele Danmarks Rige" til "Dag for Daner uden lige". Den omfattende tilskæring finder først sted i sjette og sidste strofe. Grundtvigs opfordring til den danske befolkning, især bondestanden, om at blive danskere af gavn såvel som af navn kunne forholdsvis enkelt ændres til et opmuntrende kampråb for nybyggerne i de grundtvigianske kolonier. Grundtvigs digt fra 1840'erne, forankret $\mathrm{i}$ de historiske begivenheder fra denne periode, får i omskreven version rolle som fællesskabskonstituerende samlingssang med relevans for 1890 'ernes danske nybyggere i 'Vesterlide.' Omtalte sidste strofe følger nedenfor. 
N. F. S. Grundtvigs digt:

I som bærer Rigsdagsnavnet her i Danskens Fødeland! Mindes vel, at uden Gavnet vejer Navnet ej et Gram, tomt det kun forøger Savnet: Dattersøn af Dagens Dan!

\section{F. L. Grundtvigs version:}

Dag for Daner! Frem du skride over Himlen lys og klar, straale og i Vesterlide, give dybe Længsler Svar! Op, til Daad, det er paa Tide: Dan sin store Time har.

I det foregående er arten af F. L. Grundtvigs bearbejdelser af faderens sangskat blevet belyst. Et kvantitativt perspektiv giver indblik i hyppigheden af de foretagne ændringer - små som store. I sangbogens udvidede anden udgave havde F. L. Grundtvig inkluderet $i$ alt 74 sange og salmer fra faderens forfatterskab. Af disse blev 50 optaget i sangbogen uden ændringer, herunder, som forventet, klassikere som "Den signede Dag med Fryd vi ser". ${ }^{7}$ De resterende 24 var på en eller anden vis blevet "tilskåret" som regel i form af mindre ændringer. Det vil med andre ord sige, at en tredjedel af sangbogens indhold af Grundtvigs sange og salmer var blevet ændret. Nogle af disse ændringer kan undre. Hvad kan have motiveret F. L. Grundtvig, der, som vi så, arbejdede under tidspres, til at foretage disse rettelser - på detaljeplan? Som anført i indledningen til dette afsnit skal mit bidrag til undersøgelsen af F. L. Grundtvigs bearbejdelser af faderens forfatterskab betragtes som et pilotprojekt - og en opfordring til yderligere analyse af et område, der berører et unikt samspil i ordets rige mellem to Grundtvig-generationer - N. F. S. og F. L.

\section{Repertoiret af Grundtvig-sange i sangbogens senere udgaver}

Som et sidste punkt med relation til Grundtvigs sange i "den røde" skal anføres, at de udgaver, der fulgte efter de to første under F. L. Grundtvigs redaktion, afspejler mærkbare ændringer i immigranternes tilværelse i deres adopterede hjemland. Som princip for udvælgelsen af sange til nye udgaver af "den røde" fulgte redaktørerne "Tidens Krav", et princip klart formuleret i indledningen til enhver ny udgave. Samme princip havde været ledetråden i $\mathrm{F}$. L. Grundtvigs til tider noget idiosynkratiske valg af eksempler fra den hjemlige sangskat. Det foranderlige element var sangbogens målgruppe, idet første generation efterhånden blev afløst af dansk-amerikanere født og opvokset $\mathrm{i}$ Amerika. Det betød fravalg og tilvalg i Grundtvigs forfatterskab, som skulle være i tråd med, hvad man fra sangbogsudvalgets side skønnede var behovet hos brugerne i en given periode.

For nogle af Grundtvigs sange og salmer gælder det, at de er særlig slidstærke. Et godt eksempel er det føromtalte korte digt, "Menneske 
først og Christen saa", som blev sangbogens adelsmærke. Som tidligere nævnt (se også fodnote 2) blev digtet trykt posthumt. I første udgave af 'den røde' (1888) er digtet, placeret som nummer to, udstyret med én asterisk. Den "læmpelige" ændring består i F. L. Grundtvigs omformulering af første og tredje linje: "Først Menneske ret, og Kristen saa" (i stedet for "Menneske først og Christen saa"). Det ses, at der er tilføjet et komma. I tredje linje omformuleres "Christendom vi for intet faa" til "vi Kristendom kan for intet faa" - muligvis en mere mundret formulering. Anden udgave har den oprindelige tekst af Grundtvig, dog med "Christen" stavet "Kristen", og "Christendom" ligeledes erstattet med "Kristendom". Endvidere bemærkes, at det tilføjede komma i første linje af førsteudgavens version er bibeholdt. Til og med femte udgave er digtet (anden udgaves version) placeret som nummer to i sangbogen. I de to sidste identiske udgaver, sjette og syvende, findes det i kategorien "Kristenlivet og Menneskelivet", og det har mistet sin titel ("Menneske først!"). Det væsentligste er, at det har overlevet mange år og flere udgaver. Som forventet er klassikere som "Den signede Dag med Fryd vi ser" og "Morgenstund har Guld i Mund" ligeledes at finde $i$ alle udgaverne.

Af de fem tilføjede Grundtvig-sange $\mathrm{i}$ anden udgave findes to "overlevere" - "Habor kom fra Norge" og, en lille perle af et lejlighedsdigt, "Øjeblikket for hvert et Barn / ligner en spraglet Sommerfugl." Sidstnævnte, bestånde af fem strofer, blev skrevet til Frederik VI i anledning af hans fødselsdag i 1834. Det er ikke at finde i nogen udgaver af Højskolesangbogen. I tredje udgave blev der til kernen af Grundtvig-sange fra de tidligere udgaver (51) tilføjet yderligere 37. Tredje udgaves samlede antal (88) blev i fjerde/femte udgave reduceret til 59. Endelig indeholdt sjette/syvende udgave hele 130 Grundtvig-sange og -salmer, herunder - i det engelsksprogede tillæg - salmerne "Hyggelig, rolig, Gud! er din Bolig /" og "O Kristelighed". Det skal tilføjes, at begge salmer kun findes i den engelske version. Antallet (130) skal ses i lyset af Grnndtvigs tilstedeværelse i sidste udgave (2005) af vores hjemlige Højskolesangbog - 87 sange og salmer. Af "den rødes" 130 Grundtvig-sange er et forbavsende stort antal (28) genoptryk fra de to første udgaver. De udgør med andre ord sangbogens stabile kerne af Grundtvigs sange og salmer, der har været del af immigranternes sanghverdag gennem årtier og i høj grad medvirket til at præge deres identitet og tilværelse "fjernt fra Danmark".

Sidste udgaves tilføjede sange og salmer kommer primært fra kategorierne "Kristenlivet og Menneskelivet" og "Bibelhistorie", hvorimod de, der udgør den stabile kerne i sangbogen, kommer fra grupperne "Danmark og det danske Folk" og "Skole og Folke- 
oplysning”. Et eksempel fra første kernegruppe er Grundtvigs "Fæderneland! ved den bølgende Strand" fra 1848; fra anden gruppe den ovennæunte sang "Er Lyset for de Lærde blot".

Det ses, hvorledes repertoiret af Grundtvigs sange og salmer gradvist nærmer sig indholdet i Højskolesangbogen; de perifere vækster i blomsterbedet blev luget ud til fordel for de mere almenkendte fra hjemlandets kanon. Gennem årene spillede sangbogens kerne en væsentlig rolle som brobygger mellem den gamle verden og den ny, i særdeleshed i tiden omkring århundredskiftet, da kolonierne etablerede egne danske institutioner som skole, kirke og forsamlingshus. Grundtvigs ideer om oplysning, kristendom og folkelighed udtrykt i sange egnet til fællessang, med andre ord samlingssange fungerede som en vitaminindsprøjtning af identitetsskabende og fællesskabskonstituerende betydning. Gennem årene blev disse sange en rodfæstet del af den fælles dansk-amerikanske etniske sanghukommelse.

\section{Grundtvigs forfatterskabs indflydelse på immigranternes sangproduktion}

I ovenfor citerede Dannevirke-indlæg, hvori F. L. Grundtvig gør rede for sine intentioner med hensyn til ændringer af den danske sangskat, tilføjer han, at der i sangbogen også måtte findes plads til "den Fuglekvidder, som kommer frem iblandt os, hvor fattige Tonerne end kan være, hvor lidt de end kan måle sig med dem, der fødtes hos vores Fædrelands Lærker og Nattergale" Det er især sangbogens anden, udvidede udgave, der rummer adskillige eksempler på "fuglekvidder" opstået i Amerika.

En frodig og mangefarvet sangkultur, svarende til koloniernes brogede flok af indvandrere, voksede op i de sidste årtier af det nittende århundrede og fortsatte $\mathrm{i}$ det tyvende, hvorefter den gradvist aftog for helt at slutte ved begyndelsen af anden verdenskrig. Det var første generation af danske nybyggere, der havde behov for at udtrykke sig i vers, til tider af karakteren "lirumlarum". Der var primært brug for samlingssange, men også hjemlængselssange og arbejdssange var yndede genrer. Bidragene til sangbogen kom især fra eliten af de danske indvandrere - de danske præster, forfattere, journalister og højskolelærere. Redaktør F. L. Grundtvig fandt som nævnt også plads til den jævne indvandrers produkter, eksempelvis lejlighedssange af samme type som man kunne finde i spalterne i avisen Dannevirke. Som F. L. Grundtvigs ven, gartner og bidragyder til sangbogen, E. F. Madsen udtrykte det: ${ }^{8}$ "Vi har som Folk vores egen ejendommelige Udvikling paa amerikansk Grund. Vi faar derfor vor egen Historie (...) 
Vi har saa at sige vor egen lille Have, hvori vi Aar for Aar avler flere og flere Urter til Husbehov." Madsens udtalelse er typisk for den tids immigranter - en yderst beskeden holdning til egenavlen, hvad enten den kom til udtryk i poesi eller som musik, for eksempel melodier til sangbogens indhold af især dansk-amerikanske sange.

Fra og med tredje udgave er immigrantsangene primært at finde $\mathrm{i}$ særlige grupper med betegnelserne, "Dansk-Amerikansk Ungdom" og "Danske i Amerika." I fjerde udgaves indledning (1916) er der afsat en hel side til forklaring af grupperingen af de "særlig dansk-amerikanske Sange." Redaktionen havde bestræbt sig på at gøre det "let at finde alle de Sange, der er udsprungen af det danske Folks Liv i Amerika (...)" De blev følgelig markeret med en asterisk i gruppe-indholdsfortegnelsen - med andre ord fik de en "made-in-America sticker". Af fjerde udgaves i alt 833 sange er 95 anbragt i de to ovennævnte grupper, og yderligere 44 er placeret i de for sangene passende kategorier rent tematisk. Som forventet nedskæres antallet af immigrantsange i de følgende udgaver.

To aspekter af indvandrersangenes indhold og form med relation til Grundtvigs forfatterskab er værd at bemærke. Det gælder det særlige sprog - man kunne tale om "en kode" - som bevidst eller ubevidst blev anvendt af specielt F. L. Grundtvig og hans nære kreds af grundtvigianere. Et prototypisk eksempel er digterpræsten Adam Dan, men også skribenter fra andre erhverv benyttede koden i poesi og prosa.

Det andet har at gøre med sangbogsbidrag skåret over den fædrene læst; man støder på både let genkendelige og mere subtile "ekkolinjer" fra den hjemlige sangskat, herunder velkendte Grundtvigsange og salmer. Endvidere ses det, hvorledes melodier, der i Danmark havde dannet partnerskab med de kendte tekster, i pionermiljøerne blev anvendt til de her opståede sang- og salmetekster. Disse "vandremelodier" havde vandret langt, men deres medbragte associationer var ikke desto mindre stærke og friske.

\section{Grundtvig-ameri-dansk}

Det af Grundtvig anvendte billedsprog, ord og udtryk med særbetydning (for eksempel "ordet"), som er velkendt fra hans forfatterskabs poesi, prosa og taler, udgjorde en del af de udvandrede grundtvigianeres bagage. Sproget var en integreret del af den medbragte sangarv. Der er mange eksempler på brug af koden $\mathrm{i}$ indlæg $\mathrm{i}$ avisen Dannevirke, Grundvigianernes talerør i Amerika, og den prægede ydermere den immigrantpoesi, der opstod i inderkredsen og hos andre med tilknytning til grundtvigianerne. Man kan tale om en art 
"Grundtvig-ameri-dansk", der blev del af den indvandrer-ideologi, som blev promoveret i de danske kolonier i 1880'erne. Et godt eksempel herpå er "Folkestævnets Land", en sproglig nydannelse af F. L. Grundtvig. Typisk indeholder sammensætningen ordet "folk" - et ord, som anvendt i Danmark havde konnotationer af et unikt kristeligt fællesskab. I Amerika betegnede det ligeledes et særfælleskab, her mellem de udvandrede danskere, som nok skulle knytte bånd til deres nye hjemland, men ikke lade sig absorbere i det store folkefællesskab.

Yderligere sammensætninger med "folk"og "fædre" (for eksempel, folkeliv, folkesag og folkestamme; fædrenearv og fædrenebyrd) indgik i de i Amerika opståede immigrantsange. En meget anvendt sammensætning er endvidere ordet "samlingssteder", brugt om kolonierne, og beslægtet hermed "samlingsarbejde" og "samlingssange". Endnu et eksempel på et ord, der går igen i flere af sangene, er "Vesterlide", brugt om det forjættede land, Amerika. I den stærkt ændrede sjette strofe af digtet "Dagen med sit lyse Øje", citeret ovenfor, hedder det således: "Dag for Daner! Frem du skride / over Himlen lys og klar / straale og i Vesterlide." Det er et karakteristisk træk i de af F. L. Grundtvigs ændrede sange, at meget materiale til erstatning af ord, linjer og strofer er hentet fra "Grundtvig-ameri-dansk."

De følgende to sange, et repræsentativt udpluk af tilsvarende sange, viser "ekkolinjer" med distinkt genlyd af en kendt sang af Grundtvig.

Desuden gives et eksempel på en immigrantsalme, som indgik i partnerskab med en velkendt melodi fra den hjemlige melodipulje.

O. C. Molbechs digt "At Morgenstund har Guld i Mund", som blev trykt første gang i sangbogens anden udgave, begynder alle fire strofer med linjen "At Morgenstund har Guld i Mund". Linjen giver associationer til både Grundtvigs "Morgenstund har Guld i Mund / for Natten Gud vi love" (1853) og hans digterven B. S. Ingemanns "Morgenstund har Guld i Mund / Morgensol Guds Rigdoms Væld oplukker" (1837). Begge hørte til udvandrernes medbragte sangbagage fra deres hjemland - barndommens "huskevers" - hvilket antydes i strofens første linjer. Interessant nok var det først i udgaverne efter F. L. Grundtvigs død, at Grundtvigs berømte digt blev inkluderet. I første og anden udgave af sangbogen finder vi kun Ingemanns sang. Til Molbechs sang gav F. L. Grundtvig simpelthen titlen "Morgensang".

At Morgenstund har Guld i Mund,

forstod alt vore Fædre,

og deres Arv paa fremmed Grund

vi trofast ville hædre,

saa Lyset ogsaa her faar Magt

til Kræfterne at samle, 
og ingen af os skal forsagt

om Vej i Mørket famle.

F. L. Grundtvigs sang fra den 28 juni 1885 "Bort vi stævned fra Fædres Land" var den ene af to lejlighedssange skrevet til en folkefest i byen Lake Benton i anledning af etableringen af kolonien Danebod i Tyler, Minnesota. Endnu en sang til lejligheden, forfattet af Adam Dan, blev afsunget denne dag.

"Bort vi stævned" blev en af nybyggernes mest kendte og elskede samlingssange. F. L. Grundtvig gav den titlen "Spredes og Samles" og anvendte H. Rungs melodi til "Moders Navn er en himmelsk Lyd", som bærer af en tekst med klart ekko af Grundtvigs sang (1837), for eksempel, af det kendte omkvæd "Sødt i Lyst og sødt i Nød, / Sødt i Liv og sødt i Død, / Sødt i Eftermælet!" Endelig er der i sidste strofes første linje en subtil hentydning til Grundtvigs sang "Velkommen i den grønne Lund" (1843). Nedenfor bringes første, anden og sidste strofe af det fem strofer lange digt:

Bort vi stævned fra Fædres Land, og spredtes for alle Vinde, danske Hjærter endnu dog kan en Vej til hverandre finde, sødt i Vest med Aand og Ord klinger, som i Højenord, Modersmaalets Toner.

Lad da Øjet kun dugges tit ved Mindet om Danmarks Strande, Hoved løfter vi kækt og frit som danske i Vesterlande, Hjærtebaand af Aand og Ord rækker hid fra Højenord sødt i Modersmaalet.

Vær da hilset, du grønne Vang, hvor Aanden fra Nord skal bygge, Skolen vokse med Folkesang og trives i Kirkens Skygge, sødt for Store, sødt for Smaa klinge her, mens Tiden gaa, Modersmaalets Toner.

Værdien af modersmålet - her i aktiv brug i det fremmede - blev i F. L. Grundtvigs samlingssang fuldt så markeret som i faderens velkendte sang. Som det sås i eksemplet "Dagen med sit lyse Øje", kunne et digt med tydelige referencer til den historiske tid i Danmark, i hvilken det blev til, om ikke i tilskåret form så som inspirationskilde, transponeres til en lejlighedssang for en gruppe grundtvigianere samlet i sang- 
fællesskab i forbindelse med oprettelsen af et væsentligt støttepunkt for "det danske" - en koloni.

Endelig er Adam Dans salme "Herrens Ord var dyrt i Landet" (1901) et godt eksempel på en immigrantsalme sat til en kendt, lånt melodi fra hjemlandet - $\mathrm{H}$. Rungs komposition til Grundtvigs påskesalme "Tag det sorte Kors fra Graven" (1832). I Adam Dans digt ses et tydeligt Grundtvig-forlæg. Fjerde og sidste strofe lyder:

Herrens Ord er Lys i Landet,

Selv hvor Dødens Trone staar, det gør frugtbart Ørkensandet, planter midt i Vintren Vaar, skaber Syner skaber Daad,

bryder Dødens bitre Braad, fylder Hjærterne med Glæde, saa kun Helvede maa græde.

\section{En ny generation af salme- og sangboger: Hymnal for Church and Home og $A$ World of Song}

I 1927 gik de to danske lutheranske kirker i Amerika sammen i et projekt, der resulterede i den engelsksprogede salmebog Hymnal for Church and Home $(\mathrm{HCH})$. Af dens rige indhold af salmer og åndelige sange, $\mathrm{i}$ alt 454, havde adskillige deres oprindelse i amerikanske og tyske "hymn books". Et eksempel på førstnævnte er J. S. B. Monsells salme "Sing to the Lord of harvest" (1866), placeret i gruppen "Thanksgiving".

Indholdsfortegnelsen sidst $\mathrm{i}$ bogen med angivelse af første linje af de oversatte danske salmer tæller i alt 204 bidrag, af hvilke hele 48 er af Grundtvig. Som forventet har man fra Grundtvigs forfatterskab hentet og oversat klassikere som "Den signede Dag med Fryd vi ser" (O Day full of Grace, which we behold) og "Morgenstund har Guld i Mund" (Golden light of morning bright), men også mindre kendte som "Kærlighed er Lysets Kilde" (Love, the fount of light from heaven) og "Som Dug paa slagne Enge" (Like dew upon the meadow). Som salmebogsudvalget skrev i indledningen, havde det som mål for udgivelsen, at "children, parents, and grandparents can sing together as in the days when only one language was spoken in our Church, and older people will feel more at home at our English service". Med "the hymnal" håbede man endvidere at nå ud til hele "the Lutheran Church in America".

Som det fremgår af citatet, var der brug for en salmebog, der kunne imødekomme behovet hos 1920'ernes tvedelte målgruppe bestående af på den ene side den del af menigheden, for hvem dansk i 
både tale og sang var det naturlige førstesprog, på den anden den følgende og senere generationer af dansk-amerikanere, for hvem engelsk var hovedsproget $\mathrm{i}$ de forskellige kontekster, $\mathrm{i}$ hvilke de voksede op og blev akkultureret. Det at "føle sig hjemme" under gudstjenesten havde meget at gøre med at kunne deltage i fællessangen med blandt andre Grundtvigs salmer. De yndede melodier til hjemlandets salmer - af C. E. F. Weyse, H. Rung, P. Heise, J. P. E. Hartmann og L. M. Lindeman, men også de senere, mere stringente kompositioner af Th. Laub, Oluf Ring og Carl Nielsen var det konstante samlende element. Med andre ord var melodierne bærere af det velkendte tekstrepertoire, nu i oversættelse.

De to dansk-amerikanske præster J. C. Aaberg og P. C. Paulsen havde æren for de fleste af de fine oversættelser af salmebogens danske materiale og bidrog også selv med nogle få salmer. ${ }^{9}$ Enkelte af oversættelserne er førnævnte dansk-amerikanske præst S. D. Rodholms værk, for eksempel Grundtvigs "O Kristelighed". I den engelsksprogede sangbog $A$ World of Song (AWOS), som diskuteres nedenfor, kom Rodholm til at spille en væsentlig rolle som oversætter af både danske salmer og sange, primært sidste genre.

En anekdote fra nærværende forfatters feltarbejde blandt bindestregs-danskere i Amerika tjener til belysning af sidstnævnte sangværks betydning for dets målgruppe: generationer af danskamerikanere samt "the adopted Danes". ${ }^{10}$ Hvert år i slutningen af juni afholdes der i Menucha, Oregon, en fire-dages dansk-amerikansk konference - The Danish Cultural Conference - hvis fokus er dansk og dansk-amerikansk kultur og samfund i Danmark og Amerika. I juni 1995 deltog jeg i konferencen. Et fast indslag i det daglige program er "dansk sang" enten på dansk med brug af Højskolesangbogen eller "den røde"," eller sang af danske sange og salmer på engelsk, hvor $A W O S$ er den benyttede sangbog. Et andengenerations danskamerikansk ægtepar, som i deres pure ungdom, fra 1940-41, havde været elever på grundtvigianernes Grand View College i Des Moines, Iowa, deltog med åbenlys glæde i "Danish singing". De anså AWOS som en sangbog med en særlig rolle. Som den ene af ægtefællerne sagde: "Once Danish was not spoken on a regular basis, the singing would have died out but for $A W O S$; it must truly have bridged the gap to the new generation". Sangbogen bliver også flittigt brugt ved det velbesøgte dansk-amerikanske efterårsmøde i Tyler, Minnesota, Danebod Folk Meeting. Endvidere er den en uvurderlig ressource for materiale til "song sheets" fremstillet til det årlige dansk-amerikanske forårsmøde i Solvang, Californien - The Farstrup Mortensen Lecture Series - og bliver brugt som kilde, når der til begivenheder i "the Danish-American communities" skal laves særlige "song sheets" eller 
"song booklets". Endelig fungerede den sammen med "den røde" som en uvurderlig ressource for redaktøren af ovennævnte tosprogede sangbogsudgivelse Sange for danskere: Songs of Denmark.

Første udgave af AWOS (1941) - bestående af elleve smalle lyseblå hæfter (I - XI) med charmerende forsideillustrationer passende til de forskellige hæfters indhold, samlet i mørkeblåt læderringbind er en smuk om end noget uhåndterlig sangbog. Som bogens titel antyder, dækker indholdet et vidt spektrum af sange - fra "American Songs, Spirituals and Folk Songs" (V) til "Hymns, Spiritual Songs, and Graces" (III), "Morning and Evening Songs" (I), "Danish Hymns" (II), og "Danish Folk Songs, Spiritual and Folk-life Songs" (IV), i alt 554 sange. Som redaktørerne, heriblandt den kendte danskamerikanske præst Enok Mortensen, skrev i forordet, "In times of peace, in hours of stress, at play or in worship, east, west, north, and south - everywhere - sometime, hearts and tongues sing." Grundtvig er repræsenteret med tyve sange og salmer der, som forventet, er optaget i de tre sidstnævnte hæfter. "Morgenstund har Guld i Mund" og "Den signede Dag med Fryd vi ser" (I), "I al sin Glans nu straaler Solen" (II), "Nu falmer Skoven trindt om Land" (IV) og i hæfte XI, som indeholder julesalmer og sange, hele seks bidrag af Grundtvig, herunder "Dejlig er den Himmel blaa".

Som årene gik, opstod der hos brugerne et behov for en mere handy udgave af sangbogen. Et indbundet værk i lysegrønt, nu med 386 titler, erstattede i 1958 den tidligere ringbindsudgave og blev hurtigt kendt som "den grønne". I forbindelse med en Danebod Family Camp i Tyler, Minnesota, i 1974 kom der endnu et skud på førsteudgavens stamme - Favorites from A World of Song (1974), et lyseblåt sanghæfte, som til forveksling ligner et hæfte fra førsteudgaven. Det fylder ikke mere end en tegnebog og egner sig derfor fortrinligt som sanghæfte ved dansk-amerikanske møder og sammenkomster. Sanghæftet indeholder i alt 91 af originaludgavens mest populære salmer og sange, med andre ord "the favorites". Grundtvig er repræsenteret med seks titler, de tre første ovennævnte klassikere samt følgende populære salmer og sange, "Alt staar i Guds Faderhaand." den førnævnte salme "With the Word all things began" - Rodholms digt inspireret af Grundtvigs salme og tanker om "Ordet" - og sangen "Et jævnt og muntert, virksomt Liv paa Jord.”

Da "den grønne" som målgruppe havde brugere samlet i sang ved et bredt spektrum af begivenheder, ikke blot kirkelige, kommer størstedelen af materialet i sangbogen fra genren sange, herunder materiale fra Grundtvigs forfatterskab. De inkluderede salmer er i uændret form hentet fra $H C H$. En interessant undtagelse er den ovennævnte, korte salme "Alt staar i Guds Faderhaand", hvis kendte 
omkvæd lyder: "af Guds Naade, til Guds Ære / evig glade vi skal være / i vor Herres Jesu Navn.” I P. C. Paulsens oversættelse i hymnebogen lyder omkvædet: "By His grace and to His pleasure / We His keeping gladly treasure / In the name of Christ, our Lord."

Denne oversættelse af digtet anvendes i både hymnebogen og førsteudgaven af $A W O S$. I 1958 udgaven samt i sanghæftet fra 1974 er oversættelsen erstattet af S. D. Rodholms version. Hans gendigtede omkvæd lyder: "To God's glory, by His Spirit / Joy eternal we inherit / In the name of Jesus Christ."

Prøver man at synge omkvædet, vil man hurtigt konstatere, at Rodholms version er mere sonor, betydelig mere sangbar end Paulsens. Rodholms gendigtning indeholder færre ord, færre ustemte lukkelyde og færre sibilanter, hvilket er med til at gøre omkvædet bedre egnet til sang. Samme princip gør sig gældende i den øvrige del af digtet.

For at vende tilbage til det dansk-amerikanske ægtepars udtalelse citeret ovenfor: udgivelsen af $A W O S$ var en væsentlig årsag til at dansk sang - herunder Grundtvigs forfatterskab af salmer og sange overlevede i de vanskelige år i 1930'erne, fortsatte som et væsentligt element af hjemlandets kultur hos de næste generationer af bindestregsdanskere samt er aktivt $\mathrm{i}$ brug $\mathrm{i}$ mange forskellige tokulturelle kontekster i dagens Amerika. Et symbiotisk samspil mellem melodi og tekst kendetegner de salmer og sange, som udgør den mest slidstærke del af den danske sangskat. Det var - og er - en stor udfordring for en oversætter at gendigte og samtidig tilpasse en velkendt tekst til den melodi, der har ledsaget den i en menneskealder. S. D. Rodholm tog denne udfordring op. Hans bidrag som gendigter af det danske sangmateriale, som blev optaget i 1958-udgaven af sangbogen, var fænomenalt: hele 66 gendigtninger af danske sange og salmer, større end eksempelvis J. C. Aabergs bidrag (17), og dertil kommer et bidrag på to salmer fra egen hånd. Uden tvivl har han meget af æren for, at omtalte sangkulturelle bro blev bygget mellem generationerne af dansk-amerikanere i Amerika.

Rodholms bidrag ses inden for samtlige af sangbogens genrer - fra Grundtvigs pinsesalme, hvis begyndelse citeres nedenfor, til årstidens sange (Grundtvigs "Nu falmer Skoven trindt om Land"), til menneskelivets ("Et jævnt og muntert, virksomt Liv paa Jord", ligeså citeret nedenfor), til børnesange (Peter Lembckes "Den lille Ole med Paraplyen"), til folkeviser ("Det var en Lørdag Aften"), til digt med dialektiske træk (Anton Berntsens "Mi Nååbo, Pe Sme"), til sange fra andre nordiske lande (L. Nielsens norske "Slig en Bedstemor som min") og endelig til dansk-amerikanske sange og salmer (Adam Dans "Du store frie Land"). S. D. Rodholms enestående sans for både det 
danske og det amerikanske sprogs nuancer og muligheder, linjernes prosodi og rytme og digtets metrik, kommer til udtryk i de bedste af hans gendigtninger. Netop fra denne pulje blev "gengangerne" hentet til ovenfor omtalte "song sheets". Interessant nok hører adskillige af de af Rodholm gendigtede sange og salmer til "the favorites" for mange amerikanere uden rødder $\mathrm{i}$ dansk sangkultur.

To eksempler på Rodholms gendigtninger følger nedenfor - første strofe af Grundtvigs pinsesalme med Henrik Rungs melodi:

I al sin Glans nu straaler Solen,

Livslyset over Naadestolen,

Nu kom vor Pinselilje-tid,

$\mathrm{Nu}$ har vi Sommer skær og blid, nu spaar os mer end Englerøst

i Jesu Navn en gylden Høst.

The sun now shines in all its splendor

The light of life with mercy tender;

Now bright Whitsunday lilies grow

And summer sparkles high and low;

Sweet voices sing of harvest gold

In Jesus' name, a thousand fold

og som andet eksempel, første strofe af Grundtvigs "Et jævnt og muntert, virksomt Liv paa Jord" med melodi af L. M. Lindeman:

Et jævnt og muntert, virksomt Liv paa Jord som det, jeg vilde ej med Kongers bytte, opklaret Gang i ædle Fædres Spor med lige Værdighed i Borg og Hytte, med Øjet, som det skabtes himmelvendt, lysvaagent for alt skønt og stort herneden, men, med de dybe Længsler velbekendt, kun fyldestgjort af Glans fra Evigheden.

Give me a simple life, a merry heart, And Kings may keep their pomp and garments splendid;

Let me in hut or mansion live the part

Of one from worthy ancestors descended.

With eye for things above as God ordained,

Awake to greatness, goodness, truth and beauty,

Yet knowing well the yearnings unattained,

thro' knowledge, great achievement, deeds, and duty.

\section{Grundtvigs profeti fra hans Mands Minde tale i 1838 set i lyset af sangen hos dansk-amerikanere 170 år senere.}

Yes, gentlemen, I venture to say that Denmark would feel ten times happier - and really be so - if all the new beautiful Danish songs 
which have sprung forth (...) were not simply printed on paper as now (...) but were resounding in all our schools and from there not only into the fields and forests, but also as far as the Danish flag is carried across the seas (AWOS 1941, Foreword, 15).

Ovenstående oversatte uddrag af Grundtvigs Mands Minde foredrag fra den 27. juni 1838 (Svend Grundtvig 1877, 48) er at finde i adskillige af de ovennævnte engelsksprogede udgivelser - for eksempel, AWOS og dets udløbere, diverse sanghæfter og "song sheets". To sanggrupper i staten Washington - etableret i henholdsvis 1980 og 1991, og for nylig slået sammen til én, Tacomas "Danske Sangvenner" med nu ca. 45 medlemmer - er blot et blandt mange eksempler på dansk sangs genlyd uden for Danmarks grænser, i toner af sange og salmer fra blandt andet Grundtvigs forfatterskab, båret på de velkendte melodier fra hjemlandet.

Fra et lille hæfte lavet til en nylig dansk-amerikansk begivenhed, ${ }^{12}$ der kaldte på sang, stammer følgende citat taget fra en kort profil af sanggruppen, som dens leder gennem sytten år, Inge Miller, havde forfattet om gruppens "monthly sangaften". "We usually sing from 67:30 pm, everyone gets to choose one song, either from Højskolesangbogen or the Big Blue Book, a collection of about 70 songs and 'viser', that we still add to now and again" Efter at have fortalt om det efterfølgende kaffebord, givet oplysninger om det store net af sangvenner, der samles fra mange steder i staten, og opfordret interesserede til at blive en del af sangsamværet ender Inge Miller sin profil således: "Up through the years warm friendships have been formed within the group. We have in many ways become each other's extended Danish family, brought together by our love of singing and our love for Denmark." Grundtvig ville givetvis have hilst velkommen denne facet af dansk sangs liv i det fjerne, under det vajende Dannebrog.

Ved de fælles "sangaftener" vælges sange og viser fra både Højskolesangbogen og gruppernes hæfter med yndlingssange. Efter sammenlægningen af grupperne er "den røde" normalt ikke en aktiv sangbog i sangfællesskabet, men dog en påskønnet ressource for sange, der kun er at finde heri. I Seattle-gruppen med flere andengenerations dansk-amerikanere, som var vokset op med "den røde", blev denne sangbog anvendt ved deres sangaftener i The Danish Center i Seattle.

I nærværende artikel har fokus været på nogle gunstige forhold der bidrog til Grundtvigs sanges og salmers rige liv og slidstyrke i det land, hvortil de kom, slog rod og fik ny næring af de danske emigranter og deres efterkommere. To sangbøger og en salmebog, én på hjemmesproget, to engelsksprogede, alle født i Amerika og med 
danske aner, viste sig at spille en væsentlig rolle som samlingssted for og formidler af hjemlandets sange og salmer, herunder Grundtvigs.

Med et eksempel fra Grundtvigs forfatterskab skal til slut nævnes en facet af de danske årstidssange, der er med til at berige deres liv $\mathrm{i}$ Nordamerika. Favoritsange som "Sol er oppe, / Skovens Toppe" og "Nu falmer Skoven trindt om Land" får et særligt skær, når de synges - og dermed opleves - i en kontekst fjernt fra Danmark. Ved en efterårs-sangaften hos ovennævnte sanggrupper skærpes kontrasterne mellem natur og kultur i sangenes hjemstavn på den ene side af Atlanterhavet og deres nye hjemsted på den anden. Den forudsigelige bordpynt på efterårssangaftenens kaffebord er store blodrøde ahornblade fra Washington-skovene, det forudsigelige sangvalg Grundtvigs "Høst-Sang" "Nu falmer Skoven trindt om Land", der på sin egen vis medvirker til at bringe billeder frem af de mere afdæmpede farver i hjemlandets skove.

\section{Litteraturliste}

\section{Salme- og Sangbøger}

AWOS 1941: A World of Song. Danish American Young People's League, Grand View College, Des Moines, Iowa (Hæfteudgaven)

AWOS 1958: A World of Song. The American Evangelical Lutheran Youth Fellowship, Grand View College, Des Moines, Iowa.

HCH 1927 (1952): Hymnal for Church and Home. Lutheran Publishing House, Blair, Nebraska.

Favorites from A World of Song (1974). Tyler, Minnesota.

Sangbog for det danske Folk i Amerika (1910), Tredje udgave. Aarhus. Sangbog for det danske Folk i Amerika (1916), Fjerde udgave. Aarhus.

Sangbog for det danske Folk i Amerika (1949), Sjette udgave. Blair, Nebraska.

\section{Varker af N. F. S. Grundtvig}

Grundtvig, N. F. S. (1832), Nordens Mythologi eller Sindbilled-Sprog historisk-poetisk udviklet og oplyst, København.

Grundtvig, Svend (udg.), (1877), Mands Minde 1788-1838. Foredrag over det sidste halve Aarhundredes Historie, holdte 1838 af Nik. Fred. Sev. Grundtvig. København.

Grundtvig, Svend et al. (udg.) (1880-1930), N. F. S. Grundtvigs Poetiske Skrifter, bind 1-9 (1883), København.

\section{Voerker af andre forfattere}

Dan, Adam (1889), Kilder i Dalen: Salmer og aandelige Sange, Minneapolis, Minnesota. 
Grundtvig, Frederik Lange (udg.) (1888), Sangbog for det danske Folk $i$ Amerika, Manistee, Michigan.

- (udg.) (1891), Sangbog for det danske Folk i Amerika, Anden udgave, Aarhus.

Haack, Fritz (udg.) (1980), De gamle Huskevers, København.

Holm, Søren (1955), Mythe og Kult i Grundtvigs Salmedigtning, København.

Høirup, Henning (1947), "Menneske først" i Vartovbogen, København, 127179.

- m.fl. (udg.) (1955) Frederik Lange Grundtvig, København.

- (1955) "Sangbog for det danske Folk i Amerika" i Høirup 1955, 148-161.

Ibsen, Joy (udg.) (2005), Sange for Danskere: Songs of Denmark, Songs to Live By, Trout Creek, Michigan.

Miller, Inge (2008), "Tacoma's Danske Sangvenner" i Sanghrefte til 59 $9^{\text {th }}$ Annual Pacific Northwest District Convention (April 18-20, 2008), Tacoma, Washington.

Simonsen, Henning Bredmose (1990), Kampen om Danskheden: Tro og Nationalitet i de danske kirkesamfund i Amerika, Aarhus.

Skautrup, Peter (1953) "Grundtvigs borgestuedansk" i Det Danske Sprogs Historie, Vol. III, København, $334 \mathrm{ff}$.

Stølen, Marianne (1993), Harmonien: An Ethnohistorical Sociolinguistic Analysis of a Danish-American Organization, Odense.

Toldberg, Helge (1950), Grundtvigs symbolverden, København.

\section{Noter}

$1 \quad$ Citeret i Høirup 1955, 159.

2 Se Høirups artikel "Menneske først" (Høirup 1947, 124 ff.), i hvilken han udførligt diskuterer Grundtvigs forhold til Holberg, herunder sidstnævntes indflydelse på Grundtvigs tankegang om det menneskelige og kristelige. Holberg havde i sine skrifter anvendt vendingen, "Menneske først og Kristen saa", men hans og Grundtvigs perspektiv på indholdet heraf divergerer på et væsentligt punkt: "Grundtvigs hele bibelske Syn paa Mennesket som skabt i Guds Billede, ansvarligt for Gud og bestemt til Gudssamfund - saadan kan 'den mosaisk-kristelige Anskuelse' kort sammenfattes - er uendeligt rigere end Holbergs fornuftsmæssige." (ibid., 148) Om Grundtvigs tankegang som udtrykt i hans eget digt - sandsynligvis blevet til omkring 1837 (150) - siger Høirup endvidere: "Kristendom vi for intet faa, det er den pure Lykke" - Troen er Helligaandens frie Gave. Dette er Centrum i Grundtvigs hele Teologi - den stærkeste Helligaandsteologi, der tænkes kan. Overses dette, vil hans Syn paa det menneskelige og det kristelige bestandig glide en af Hænde" (149). Som Høirup yderligere anfører, lod Grundtvig sandsynligvis aldrig digtet gaa i trykken. Først i 1881 lod J. Kristian Madsen det trykke i "Efterslæt af Grundtvigs Salmesang", som udkom 1881 (159). Høirup henviser endvidere til Madsen, som har gjort opmærksom på, at digtet ikke skulle være læst for Grundtvig eller billiget af ham (151). Mangfoldige andre steder 
har Grundtvig i digt og prosa "fremstillet sine Tanker bedre". Ifølge Høirup vil en analyse af disse steder - til belysning af digtet - "være den eneste anstændige Fremgangsmaade overfor en Digters hengemte Udkast" (151).

3 Rodholms fire-strofers digt har som muligt digtforlæg Grundtvigs "Ordet med sin Klang i Røsten".

4 F. L. Grundtvigs Dannevirke-indlæg, citeret af Høirup, er fra hhv. 26/1 1887 og $9 / 51888$.

5 Høirup, 151.

6 Svend Grundtvig (1880-1930), bd. 5, 61.

7 Af gode grunde hører Grundtvigs salme med blandt de 96 af Kulturministeriets kanonudvalg håndplukkede kunstværker til "Den fælles kanon" anno 2005.

8 Citeret af Bredmose Simonsen 1990:181.

9 Der er yderligere nogle få bidrag af de dansk-amerikanske digterpræster Adam Dan og Kr. Østergaard. Sidstnævntes to-strofers digt "Herre, jeg vil gerne tjene" [Lord, I wish to be Thy servant] (1891), oversat af J. C. Aaberg, er som det eneste dansk-amerikanske bidrag at finde i Den danske Salmebog (2003). I udgivelsens oplysninger om salmebogens forfattere står der om Kristian Østergaard: "højskoleforstander i Støvring, dansk præst i USA." I "den røde", hvor digtet blev optaget i gruppen "Kristenlivet og Menneskelivet" får man følgende interessante informationer om digtet og dets forfatter: "Af Dagbogen 1891, Aaret før Forfatteren opgav sin Højskole i Danmark og vendte tilbage til Amerika."

10 Termen 'The adopted Danes' anvendes af dansk-amerikanere i Amerika til betegnelse for de mennesker, der ikke har slægtskabsbånd til danskere, men via f.eks. ægteskab eller venskab er blevet inkluderet i det danskamerikanske fællesskab - en klub, gruppe eller selskabelig begivenhed.

11 Indtil 2001 blev "den røde" anvendt side om side med Højskolesangbogen. Grundet transportvanskeligheder (de mange eksemplarer af sangbogen skulle bringes helt fra Seattle til Oregon) blev det bestemt at nøjes med Højskolesangbogen som dansksproget sangbog og $A$ World of Song til brug under sangen på engelsk.

12 The $59^{\text {th }}$ Annual Pacific Northwest District Convention i Tacoma, Washington, hvor Tacomas "Danske Sangvenner" ledede fællessangen. Det ti-siders sanghæfte med smukke farvefotos som supplement inkluderede elleve sange, deriblandt tre engelsksprogede (for eksempel, Amerikas og Canadas nationalsange) og flere klassikere fra det velkendte danske repertoire, herunder "I Danmark er jeg født." 